\title{
Exploring Saudi Pre-service Teachers' Knowledge of Critical Thinking Skills and their Teaching Perceptions
}

\author{
Amani K. Gashan \\ College of Education, King Saud University, Saudi Arabia \\ E-mail: ebra1982@hotmail.com
}

Received: $15-12-2014$

doi:10.7575/aiac.ijels.v.3n.1p.26
Accepted: 28-01-2015

URL: http://dx.doi.org/10.7575/aiac.ijels.v.3n.1p.26
Published: 30-01-2015

\begin{abstract}
The current study aimed to investigate Saudi pre-service teachers' knowledge about the general concepts of critical thinking, as well as its skills. In addition, the study explored their perceptions about critical thinking and its teaching in classrooms with an aim to develop learning and teaching process. The study was conducted with twenty-nine male students at a teacher education program in the College of Education, King Saud University. The quantitative method was used, employing a three-part instrument. The quantitative data was analyzed with SPSS software program (ver. 20.0), using sums, means and standard deviations of pre-service teachers' responses on the questionnaires. According to the findings of the current study, pre-service teachers who were enrolled in the College of Education were found to have inadequate knowledge about critical thinking skills. Although, the present study concluded that pre-service teachers held positive opinions about the value of teaching critical thinking, they generally had unsure knowledge about critical thinking. They expressed that they are not sure if they had the skills necessary to promote critical thinking by students in their classes. The current study recommends that education preparation programs are in need to be reviewed and specialized courses in critical thinking skills need to be incorporated. Pre-service teachers' knowledge about critical thinking should be enhanced to enable them reflect what they have of skills on their future teaching duties. More exploration is suggested to explore critical thinking knowledge among college teachers and to examine their methods of teaching critical thinking.
\end{abstract}

Key words: perceptions, pre-service teachers, critical thinking

\section{Introduction}

From Socrates to contemporary scholars, there have been continuous calls for the need of educated citizens and qualified workforce and citizens' capability to think critically. As the world is moving toward a technology-based economy, facing worldwide competition, there is a growing need for workers with analytical thinking skills who have the ability to integrate information from a wide range of sources and competently make fruitful decisions. In a complex and swiftly altering world, critical thinking is an essential tool in order to successfully perform in the competitive life.

In the twentieth century, Dewey (1938) argued that learning to think is the fundamental objective of education. The emphasis has been shifted from imparting information and content to the learners, to enhancing their thinking skills. Ashraah, AL-Nabrawi, Shdeifat, and Al-Ali (2012) stated that education systems in almost all over the world are shifting their focus to improving learners' higher mental processes comprising critical thinking, and problem solving.

Howie (2011) highlighted that the ability to think critically is one of the highest levels of mental activity. It empowers people to engage in the practices of making decisions and organizing work (Alazzi \& Khawaldeh, 2008). In order to meet marketplace demands and solve societal and modern everyday life problems, it is crucial to develop learners' cognitive skills to help them be successful in their upcoming life plans in various fields. Gaining the ability to think critically could assist learners to form their thoughts and ideas instead of just repeating and following those of others, by activating their intellectual abilities to evaluate different perspectives and viewpoints. A critical reason for developing learners' mental abilities through the school context, as suggested by Alwadai (2014), is to further develop learner s' mental growth by offering them practical chances that could challenge their thinking processes. Thus, it is the teacher's role to train learners to think critically and push them to activate their higher thinking abilities.

Allamnakhrah (2013) asserted that the Saudi educational system should be reformed and reshaped toward central life skills. This enhancement is indispensable as Saudi Arabia moves toward a modern global competitive life. Consequently, global competition calls for analytical and critical thinkers who can make efficient and profitable decisions. Alwehaibi (2012) highlighted the main concerns of the Saudi educational system as to arm pupils with the foundation skills essential to flourish in a changing world.

Obviously, the ability to think is a natural process, but this skill needs to be enhanced by teachers. Moreover, the way teaching material is presented could play an essential role in improving critical thinking. Lauer (2005) argued that teachers might not be fully aware of the methods and strategies to integrate critical thinking skills into their teaching classes. As the college may obviously lean on traditional lectures and PowerPoint presentations, this might be the 
reason that teachers face trouble when trying to integrate critical thinking into their classes. Ozkan-Akan (2003) stressed that the perceptions of teachers have an obvious impact on the improvement of students' critical thinking abilities. Equally, teachers' lack of adequate theoretical and practical awareness of critical thinking skills is possibly obstructing their proficient ability to facilitate the enhancement of critical thinking skills among their students (Kowalczyk, Hackworth \& Case-smith, 2012). Furthermore, without the exact knowledge and right perceptions of critical thinking, teachers may think they are doing the right job in enhancing their learners' critical thinking when unfortunately they are not. To explore this issue in greater detail, this study was developed to determine the extent of knowledge pre-service teachers have about critical thinking, as well as their current perceptions about critical thinking instruction.

\subsection{Significance of the Study}

Research should be increasingly conducted to better understand the efficient means to enable teachers to fulfill their teaching duties and help their students acquire critical thinking skills. Understanding the teachers' perceptions and level of knowledge about critical thinking skills would provide useful information to enhance teacher educational programs. The current study attempted to contribute to the process of improving the Saudi educational system by examining the pre-service teachers' knowledge and perceptions about critical thinking skills. This study may help the decision-makers get useful suggestions about the teacher candidates' preparation programs.

\subsection{Statement of the Problem}

The intent of this explanatory study was to explore pre-service teachers' knowledge regarding critical thinking skills. The goal of this study was to investigate the perceptions of pre-service teachers toward the teaching of critical thinking skills in Saudi Arabia. Teachers play a very critical role in the learning process and personal skills of their learners. They can significantly reinforce the way their learners think. Thus, their perceptions toward teaching critical thinking skills and their lack of adequate awareness of thinking skills can also be a limitation to their ability to assist the learning process (Kowalczyk et al., 2012).

Teachers may intend to teach at a higher level, which would contain critical thinking skills, when unfortunately, their perception and knowledge about this subject is inadequate. There is an empirical gab of information regarding the perception of pre-service teachers about the teaching of critical thinking skills, as well as the actual knowledge they have regarding critical thinking concepts. Gathering such information would be a valuable stage in igniting the process of establishing a model of providing the best quality critical thinking instruction in their classrooms.

Sng (2011) suggested that critical thinking skills may vary depending on the varieties of cultures, values and educational backgrounds. This means that critical thinking cannot be connected to intellectual skills alone. The way we think critically about the world around us is deeply affected by the construction of morals, principles, and spiritual views. Thus, the current study was intended to examine the knowledge and perceptions of critical thinking of Saudi Arabian pre-service teachers. The aim of the current study was to explore the patterns of pre-service teachers' understanding of basic critical thinking concepts and personal perceptions regarding critical thinking instruction.

\subsection{Objectives of the study}

The objectives of the present study are:

(1) To identify the knowledge of the Saudi pre-service teachers regarding critical thinking skills.

(2) To explore the perceptions of the Saudi pre-service teachers on the critical thinking skills.

(3) To make practical recommendations based on the findings of the study regarding the implementation of the critical thinking in the Saudi educational context.

\subsection{Research Questions}

This study addressed the following research questions:

1. What is pre-service Saudi teachers' knowledge regarding the critical thinking skills?

2. What are the perceptions of pre-service male Saudi teachers, enrolled in college of Education, regarding critical thinking skills?

\section{Theoretical Background}

Critical thinking was defined by Facione (1990) as "purposeful, self-regulatory judgment, which leads to interpretation, analysis, evaluation, and inference, as well as explanation of evidential, conceptual, methodological, or contextual considerations upon which that judgment is based". The definitions of critical thinking are diverse in terms of breadth or inclusiveness. Alazzi and Khawaldeh (2008) suggested a definition for critical thinking as the cognitive processes and strategies involved in decision-making, problem solving, or inquiry. They further narrowed their definition as an indispensable component of common cognitive processes, such as problem solving or decision-making, but were not identical with them. Recently, Weissberg (2013) argued that the definitions of critical thinking are varied, but still have certain traits in common, remarkably the capability to invest reason to go further beyond the process of acquiring facts to reveal deep meaning. Critical thinking could be noticed as sharing two main features: 1) a set of information and beliefs generating and processing skills, and 2) the habit, grounded on intellectual obligation of using those skills to lead performance.

The focus of enhancing critical thinking skills has enlarged swiftly since the $21^{\text {st }}$ century, and has become the most significant criterion for assessing school curriculum outcomes (Klein, 2011). Howie (2011) emphasized the significant status of developing learners' critical thinking skills within the school curriculum to enable them to solve personal and 
social problems, thus becoming more productive and active. Besides, critical thinking has lately come to be a crucial qualification required by businesses seeking solutions to modern life problems and to effectively compete on the international business market (Alazzi, 2008)

Refining learners' critical thinking skills is a key role of schools. Smith (2002) argued that the significance of enhancing learners' critical thinking skills has been increased in the few last decades, as they are indispensable core life skills. McGuinness (2005) highlighted the importance of improving these skills to learners in order to enable them to become higher-level thinkers, and as a result prepare them to become tomorrow's leaders.

Teachers' perceptions play an influential impact on the way they adopt teaching techniques, use of a variety of assessment instruments, as well as their students' learning performance. Therefore, the need to emphasis on teachers' perceptions has become a major topic for educational leaders to enhance their educational system (Alwadai, 2014).

Exploring teachers' perceptions and awareness regarding critical thinking have been the focus of an increasing body of literature in teacher education (Qing, Chungeng, Shuyu, Liya, \& Lijuan, 2012; Ashraah et al., 2012). Recent studies highlighted that what teachers believe about critical thinking has an obvious impact on how they interact with their students and organize classroom tasks (Qing et al., 2012). It is believed that in order to encourage learners to think critically, the passive receipt of information needs to be replaced. Teachers have to discontinue the perception that learners are not capable to learn unless a teacher covers the whole material (Choy \& Cheah, 2009). Rather, it is critical to reflect on how much impact a teacher's perception of critical thinking has on the learners' readiness to learn and think critically.

In a comparative study in Chinese context, Qing et al. (2012) explored the pattern of critical thinking that middle school sixty-nine in-service and sixty-one pre-service teachers hold. The authors made use of the California Critical Thinking Skills Test (CCTST) to judge their critical thinking. The findings showed that the teacher' scores of critical thinking skills were very low. The study also indicated that there were statistically significant differences between in-service and pre-service teachers regarding their critical thinking skills. Additionally, mean scores reflected that the pre-service chemistry teachers performed better than the in-service teachers did.

In a qualitative study by Alazzi (2008), the researcher interviewed high school social studies teachers regarding their perceptions on teaching critical-thinking skills in their classrooms. The research's findings indicated that Jordanian teachers showed immature awareness of the definition and teaching strategies of critical thinking. The researcher stated that teacher's guidebook provides comprehensive content information, with only minor references to teaching critical thinking. Alazzi further argued that his previous research, conducted on middle and high school learners in Jordanian public schools, supported the results that learners did not acquire critical-thinking skills from their public school education in Jordan. Similarly, in the Jordanian context, Ashraah et al. (2012) conducted a study to investigate the critical thinking skills of Islamic Education's teachers and to highlight the effect of gender, length of experience and qualifications on their critical thinking skills. Unlike Alazzi (2008) study's findings, the results found that teacher's level of critical thinking skills are high. The study failed to find any significant differences related to gender variable, though there were significant differences related to experience and scientific qualifications variables.

Semmar, and Fakhro's (2009) study investigated how elementary school teachers in Qatar could encourage students' critical thinking skills in their classrooms. A critical thinking skills' questionnaire based on Bloom's taxonomy of educational objectives, cognitive domain, was conducted to explore teachers' frequency of using certain critical thinking activities. Results found significant differences between public schools and private ones on the application, analysis, synthesis, and evaluation levels, but not on knowledge and comprehension. No significant differences were observed between the two types of teachers, based on years of teaching experience.

The concept of critical thinking has received little attention in literature related to Saudi schooling. Few published studies have examined the perceptions and knowledge of teachers about critical thinking skills in Saudi context. AlHamdi's study (2004) was undertaken to explore the reality of practicing that history teachers perform regarding critical thinking skills in their classrooms. Findings concluded that there were significant differences between teachers who teach critical thinking skills in their classes and the acceptable educational level.

In a qualitative case study conducted at King Abdul Aziz University and Arab Open University, Allamnakhrah (2013) investigated students' perception of learning critical thinking in secondary pre-service teacher education programs in Saudi Arabia. The findings highlighted the need for education reforms based on critical thinking to elevate the quality of education in Saudi Arabia. The core result to emerge from the interviews was that critical thinking was seen very important skill by all participants interviewed. However, they stated that critical thinking was not the basis of preservice teacher education programs at both universities in Saudi Arabia. In a more recent study, Alwadai (2014) investigated Islamic teachers' views on developing critical thinking skills in elementary schools in the southwestern province of Saudi Arabia. The study explored the factors that may affect their employment of critical thinking instruction. The study concluded that Saudi teachers failed to teach critical thinking skills, and apply them in their classrooms to their students due to their own lack of knowledge of critical thinking skills. The study reported seven major obstacles of teaching critical thinking, which are student ability, teaching methods, classroom structure, Saudi society and the school community, pre-service teachers preparation programs and in-service teachers' professional developmental programs, and the Islamic studies curriculum.

Reviewing the previous studies, it could be concluded that while in-service teachers' perceptions of critical thinking have been the focus of many studies in several parts of the world, fewer studies have been conducted to explore pre- 
service teachers' perceptions and knowledge of critical thinking skills. There has been no research undertaken in secondary pre-service teacher education programs in Saudi Arabia, except for the study of Allamnakhrah (2013) which was a qualitative case study. There was almost no study, as far as the researcher knows, conducted to explore the preservice knowledge about critical thinking skills, which is the scope of the current study. Alwadai (2014) suggested that there is a need to examine perceptions of teachers of other disciplines such as social science, English, and math, in an effort to provide policy makers in the Ministry of Education with a holistic picture of the Saudi educational system. He further suggested that more research is needed on the pre-service education programs in terms of critical thinking skills.

\section{Methodology}

To accomplish the objectives and fulfill the purpose of the study, the quantitative method was used to collect responses of the participants. The study employed a survey design. Stedman, and Adams (2012) argued that this approach is appropriate for such a study.

\subsection{Participants}

Participants of the currents study were twenty-nine students enrolled in pre-service teaching program in Education College at King Saud University during the academic year 2014/2015. The participants were selected using a simple random selection. The majority of them will be teachers after graduation.

\subsection{Data Collection Instrument}

A Three-part instrument was used in the study. The first one is short demographic information about respondents including terminal degree, specialization, level of study, and previous experience (training courses/ programs) in critical thinking, as well as courses related to critical thinking in the college level study.

The second one is to measure the participants' knowledge about critical thinking. It consisted of three sections adopted from Elder et al, (2007), and Al-degether (2009). The first section has sixteen statements that required participants to select the skills that are related to critical thinking. The participants were required to identify these skills by selecting "Yes" if they thought that the statement was one of critical thinking skills or choosing "No" if they thought that the presented statement was not a skill of critical thinking. The second section includes six multiple-choice questions to determine the accuracy of an individual's knowledge of critical thinking.

The third section is on the nature of critical thinking, had nine true/false statements designed to gauge an individual's familiarity with specific critical thinking statements. For this part, that assesses pre-service teachers' knowledge about critical thinking, mean scores ranging from $(0)$ to $(0.35)$ reflected an inaccurate awareness of critical thinking. Mean scores ranging from $(0.36)$ to $(0.65)$ showed that the respondents had uncertain understanding of critical thinking, and mean scores ranging from (0.66) to (1) indicated that pre-service teachers had accurate knowledge about critical thinking.

The third part was revised by Stedman and Adams (2012) from a list of questions first proposed by Choy and Cheah (2009). This part is intended to gauge participants' perceptions of critical thinking and critical thinking instruction. The revised questionnaire is comprised of 14 Likert-type statements using a scale of 1 (Strongly Disagree) to 5 (Strongly Agree). Mean score within the range of (1 to 2.4) indicated disagreement opinion toward teaching critical thinking. Mean scores of (2.5 to 3.4) indicated neutral opinion of teaching critical thinking. Means score within the range of (3.5 to 5) indicated strong agreement about teaching critical thinking.

Further, the researcher translated the instrument into Arabic language and it was reviewed by a group of five educational specialists to check its face validity. The Arabic version was discussed and revised until an agreement was reached on the final survey tool. Reliability was calculated by using testing and re-testing (test-retest) method and through the application of the questionnaire on an exploratory sample which consisted of (9) pre-service teachers. The calculated Pearson correlation coefficient was $(0.88)$. The stability coefficient was calculated according to the equation of internal consistency (Cronbach alpha), and the value of stability coefficient was (0.93). These values were considered appropriate for the purposes of the study.

\subsection{Procedure}

During the first semester in the study year 2014/2015, questionnaires were distributed to the pre-service teachers in classroom after class. Pre-service teachers participating in the study were provided with a verbal explanation of the study. Upon initial review of the data, seven responses were determined to be unusable, resulting in twenty-nine usable responses. To answer the question of the study, the following data analysis method was used: sums, means and standard deviations of teachers' responses on the questionnaires. The survey collected demographic data in order to identify the make-up of the responding sample. The quantitative data was analyzed with SPSS software program (ver.20.0).

\section{Results and Discussion}

This study was conducted to explore pre-service teachers' knowledge and perceptions about critical thinking. Survey research was conducted using the questionnaire instrument. To answer the research questions, statistical analysis of this study utilized descriptive statistics.

The first question was to identify the patterns of knowledge of pre-service Saudi teachers regarding the critical thinking skills. This was accomplished through a systematic review of individual responses on the second part of the questionnaire with its three sections. The first section of this part explored pre-service teachers' knowledge regarding the skills and sub-skills of critical thinking. 
Table 1. Sum, Mean and Standard Deviation (SD) for Knowledge about Critical Thinking skills

\begin{tabular}{lllll}
\hline \multicolumn{1}{c}{ The skill } & Sum & Mean & SD \\
\hline 1- & Examining relationships among statements. & 18 & 0.620 & 0.493 \\
2- & Interpreting the meanings from variety of data or experiences. & 22 & 0.758 & 0.435 \\
3- & Assessing the quality of ideas or data. & 24 & 0.827 & 0.384 \\
4- & Identifying alternative claims and drawing conclusion. & 20 & 0.689 & 0.470 \\
5- & Presenting results of one's reasoning. & 20 & 0.689 & 0.470 \\
6- & Generating original and new insights. & 13 & 0.448 & 0.506 \\
7- & Delivering information that committed to memory. & 15 & 0.517 & 0.508 \\
8- & Generating questions from a particular topic. & 6 & 0.206 & 0.412 \\
9- & $\begin{array}{l}\text { Confirming, validating, or correcting one's reasoning } \\
\text { procedure. }\end{array}$ & 18 & 0.620 & 0.493 \\
10- & & 15 & 0.517 & 0.508 \\
11- & Storing, retaining, and recalling information. & 13 & 0.448 & 0.506 \\
12- & Separating relevant from irrelevant data. & 21 & 0.724 & 0.454 \\
13- & $\begin{array}{l}\text { Moving from a question or a problem toward one correct } \\
\text { answer or a solution. }\end{array}$ & 13 & 0.448 & 0.506 \\
14- & $\begin{array}{l}\text { Making a prediction of what will happen in the future from } \\
\text { given information. }\end{array}$ & 12 & 0.413 & 0.501 \\
15- & Summarizing an article in one's own words. & 22 & 0.758 & 0.435 \\
16- & $\begin{array}{l}\text { Analyzing an argument through sketching a graph or drawing a } \\
\text { picture. }\end{array}$ & 15 & 0.517 & 0.508 \\
\hline
\end{tabular}

In the previous section of the questionnaire, participants were required to distinguish the skills that were related to critical thinking. As could be seen in the table (1), no participant could correctly identify all the skills. The findings showed that the means of nine out of the sixteen items existed in the $(0.36-0.65)$ range, which indicated that the majority of the respondents had uncertain understanding of critical thinking skills. Only five out of sixteen statements existed in the high range (0.66-1). The last one item was fitted in the low range $(0-0.35)$ with only six correct answers out of twenty nine answers.

Table 2. Sum, Mean and Standard Deviation (SD) for Knowledge about Critical Thinking skills

\begin{tabular}{|c|c|c|c|}
\hline The Statement & Sum & Mean & SD \\
\hline $\begin{array}{l}\text { 1- It is important to clarify thinking whenever you are explaining } \\
\text { something to someone; whenever someone is explaining something } \\
\text { to you and; whenever you are analyzing an article or chapter. }\end{array}$ & 21 & 0.724 & 0.454 \\
\hline $\begin{array}{l}\text { 2- Fair-minded thinking is connected with the accurate assessment of } \\
\text { one's own reasoning. }\end{array}$ & 4 & 0.137 & 0.350 \\
\hline $\begin{array}{l}\text { 3- Depth in reasoning best relates to complexities in the issue; logical } \\
\text { interpretations; clarifying the issue. }\end{array}$ & 12 & 0.413 & 0.501 \\
\hline $\begin{array}{l}\text { 4- One main requirement of critical thinking is to analyze thinking } \\
\text { into its most basic components. }\end{array}$ & 13 & 0.448 & 0.506 \\
\hline $\begin{array}{l}\text { 5- Critical thinkers assess thinking in order to determine what } \\
\text { thinking to accept and what to reject }\end{array}$ & 10 & 0.344 & 0.483 \\
\hline $\begin{array}{l}\text { 6- An important fact that supports the need for an analytic dimension } \\
\text { of critical thinking is that the analysis of thinking is presupposed in } \\
\text { every subject. }\end{array}$ & 10 & 0.344 & 0.483 \\
\hline
\end{tabular}

In the second section, there were a total of six statements to decide pre-service teachers' familiarity with critical thinking concepts. Participants were required to select the correct completion of the statement out of four choices. Again, there was no single question where all respondents answered correctly, and only one mean score (0.72) existed in the high range $(0.66-1)$. The rest of the means was within the average and low range, with the second statement, "Fair-minded thinking was connected with the accurate assessment of one's own reasoning", being answered correctly with only four participants out of twenty-nine teacher students. 
Table 3. Sum, Mean and Standard Deviation (SD) for Knowledge about Critical Thinking skills

\begin{tabular}{llll}
\hline \multicolumn{1}{c}{ The Statement } & Sum & Mean & SD \\
\hline 1- As people grow older, they naturally develop as critical & 4 & 0.13 & 0.350 \\
thinkers. & 16 & 0.55 & 0.506 \\
2- Critical thinking is self-disciplined. & 15 & 0.51 & 0.508 \\
3- Critical thinking enables one to think more deeply. & 18 & 0.62 & 0.493 \\
4- One should not analyze sympathetically points of view that are & & & \\
disgusting and obviously false. & & 0.65 & 0.483 \\
5- If a statement is unclear, we benefit by asking what our purpose & 19 & & \\
is in saying it. & 15 & 0.51 & 0.508 \\
6- Implications are conclusions you come to in a situation. & 16 & 0.55 & 0.506 \\
7- Critical thinking is important in learning to read well. & 19 & 0.65 & 0.483 \\
8- Critical thinkers use subjective standards to assess thinking. & & 0.493 \\
9- Critical thinkers learn to ignore their emotions when making & 18 & 0.62 & 0.493 \\
important decisions. & & & \\
\hline
\end{tabular}

As could be seen in table (3), the third section included nine true/false statements exploring pre-service teachers' knowledge regarding the nature of critical thinking. Similarly, there was no single statement that participants correctly agreed about. Out of nine statements, there was no mean score of any statement that existed in the high range. The means of nine statements were found to exist in the average range, which means that pre-service teachers had uncertain understanding of the nature of critical thinking. The mean score $(0.13)$ of the first statement, "as people grow older they naturally develop as critical thinkers", fitted in the low range, with only three correct responses.

Findings about pre-service teachers who are enrolled in the college of education showed that teachers had almost poor knowledge regarding critical thinking skills, which in turn indicated that teacher students needed more college preparation about critical thinking. These findings are in line with the previous study of Alwadai (2014). Alwadai found that Saudi in-service teachers failed to teach critical thinking skills due to their weak awareness of critical thinking skills and their classroom application. Lauer (2005) argued that colleges might not have all the tools necessary to incorporate critical thinking into their courses. Allamnakhrah (2013) concluded that critical thinking is not the basis of pre-service teacher education programs in Saudi Arabia. In addition to the previous justification, Education College teachers might think that they are teaching critical thinking properly, when they are not. Moreover, college teachers might not have an adequate critical thinking education themselves.

To answer the second question, the third part of the questionnaire explored the perceptions of pre-service male Saudi teachers, enrolled in College of Education, regarding critical thinking skills.

Table 4. Sum, Mean and Standard Deviation (SD) for Perceptions on Critical Thinking Skills

\begin{tabular}{|c|c|c|c|}
\hline Statement & Sum & Mean & SD \\
\hline $\begin{array}{l}\text { Critical thinking engages students' higher order thinking (analysis, } \\
\text { synthesis, and evaluation). }\end{array}$ & 120 & 4.14 & .639 \\
\hline $\begin{array}{l}\text { 2- Critical thinking encourages students to become independent } \\
\text { thinkers. }\end{array}$ & 123 & 4.24 & .739 \\
\hline Critical thinking encourages students to become active learners. & 124 & 4.28 & .702 \\
\hline Critical thinking can be used to achieve better learning outcomes. & 120 & 4.14 & 639 \\
\hline $\begin{array}{l}\text { 5- Critical thinking will allow students a better understanding of } \\
\text { course topics. }\end{array}$ & 116 & 4.00 & .535 \\
\hline $\begin{array}{l}\text { 6- I believe that it is my responsibility to promote critical thinking in } \\
\text { my courses. }\end{array}$ & 107 & 3.69 & .891 \\
\hline $\begin{array}{l}\text { 7- Critical thinking is a method of thinking which would help } \\
\text { students enjoy the learning process. }\end{array}$ & 116 & 4.00 & .535 \\
\hline Critical thinking should always include a reflective component. & 125 & 4.31 & .891 \\
\hline I am aware when students use critical thinking in my courses. & 77 & 2.66 & 1.078 \\
\hline $\begin{array}{l}\text { 10- I look for specific evidence of critical thinking by students in my } \\
\text { courses. }\end{array}$ & 82 & 2.83 & .848 \\
\hline $\begin{array}{l}\text { 11- I have the skills necessary to promote critical thinking by students } \\
\text { in my courses. }\end{array}$ & 58 & 2.00 & .926 \\
\hline $\begin{array}{l}\text { 12- I think that students have barriers to critical thinking, regardless of } \\
\text { the strategies I use }\end{array}$ & 48 & 1.66 & 0.769 \\
\hline 13- If required, I could implement critical thinking into my courses & 62 & 2.14 & 0.915 \\
\hline $\begin{array}{l}\text { 14- In order for me to fully implement critical thinking into my } \\
\text { courses, I would need additional support. }\end{array}$ & 113 & 3.90 & 1.081 \\
\hline
\end{tabular}


Data analysis of the perceptions scale showed that the means of nine statements out of fourteen fell into the high range of agreement. Participants expressed their strong agreement $(\mathrm{M}=4.31)$ with the statement "Critical thinking should always include a reflective component". The second highest mean $(\mathrm{M}=4.28)$ was recorded for the statement: "critical thinking encourages students to become active learners". Participants strongly agreed $(M=4.24)$ that "critical thinking encourages students to become independent thinkers". With high mean score of $(\mathrm{M}=4.14)$, pre-service teachers equally agreed that "critical thinking engages students' higher order thinking", and that "critical thinking can be used to achieve better learning outcomes. In addition, they recorded high agreement $(\mathrm{M}=4.0)$ about the fifth and seventh statements. Participants stated that critical thinking would allow students a better understanding of course topics. They also argued that critical thinking is a method of thinking which would help students enjoy the learning process. As pre-service teacher, participants believed that it was their responsibility to promote critical thinking in their courses, with a high mean score of (3.69). Pre-service teachers were found to hold positive opinions towards critical thinking and teaching its skills. These results are consistent with findings of Allamnakhrahs' (2013) study. The researcher concluded that critical thinking was seen very essential by all participants interviewed. Notably, pre-service teachers who participated in the present study showed their need for additional support, in order for them to fully implement critical thinking into their courses $(\mathrm{M}=3.90)$.

Within the average range of mean score (2.83), participants were not sure about the statement that "they look for specific evidence of critical thinking by students in their course". They also expressed their doubt about their awareness of when their students use critical thinking in their courses $(\mathrm{M}=2.66)$. The lowest means were recorded in the statements number thirteen, twelve, and eleven. Most of the participants disagreed $(M=2.14)$ that if required, they could implement critical thinking into their courses. They also expressed their disagreemt $(M=2.0)$ about the statement that they had the skills necessary to promote critical thinking by students in their courses. These findings could be justified as pre-service teachers probably did not have an adequate knowledge about the methods and strategies to incorporate critical thinking skills into their lessons (Lauer, 2005). Kowalczyk, et al. (2012) argued that teachers' absence of sufficient awareness of critical thinking skills could have the potential to hinder their ability to assist the teaching of critical thinking skills among their students. However, the least mean $(M=1.66)$ was recorded for the twelfth statement which indicated that pre-service teachers generally did not think that their student had barriers to critical thinking.

\section{Conclusion}

According to the findings of the current study, pre-service teachers who were enrolled in the College of Education were found to have inadequate knowledge about critical thinking skills. The present results are in line with some previous studies (Lauer, 2005; Alazzi, 2008; Stedman \& Adams, 2012; Qing et al., 2012 Alwadai, 2014) that found teachers to have unsure knowledge about critical thinking. When taking into consideration that none of the questionnaire's statements that explored critical thinking knowledge, was answered correctly by all respondents, one may believe that the college's programs need to incorporate more instruction when it comes to teaching critical thinking. Stedman andAdams (2012) argued that critical thinking is an important component to higher education. In Alwadai's study (2014), the findings concluded that Saudi teachers failed to teach critical thinking skills to their students due to their own lack of knowledge of critical thinking skills, and how to apply them in their classrooms. The study reported that one major obstacle was the weakness of pre-service teachers' preparation programs. Encouraging college teachers to incorporate critical thinking components into their lectures will support pre-service knowledge regarding critical thinking.

The present study found that teachers held positive opinions about the value of teaching critical thinking. Saudi preservice teachers were found to strongly agree that critical thinking engages students' higher order thinking, and supports them to become independent thinkers, and active learners. They argued that critical thinking would allow students a better understanding of course topics, enjoy the learning process, and achieve better learning outcomes.

However, the participants doubted as to whether they knew when students used critical thinking in their courses. They further expressed their disagreement that they had the skills necessary to promote critical thinking by students in their courses, and consequently be able to implement critical thinking into such courses. These findings reflect their lack of adequate knowledge of critical thinking as shown previously. Tarman (2012) concluded that it would be possible to adjust teachers' prior perceptions by offering them qualified developmental programs.

The current study recommends that education preparation programs need to incorporate specialized courses in critical thinking skills. Pre-service teachers are required to be fully aware of critical thinking skills, and the best strategies to teach them later in their classes. Further investigation is necessary to explore critical thinking knowledge among college teachers. More investigation is also suggested to better understand how college teaching members are prepared to teach critical thinking.

\section{Acknowledgements}

The author would like to extend their appreciation to the College of Education Research Center, Deanship of Scientific Research, King Saud University, for funding this research work. 


\section{References}

Alazzi, K. F. (2008). Teachers' Perceptions of Critical Thinking: A Study of Jordanian Secondary School Social Studies Teachers. Social Studies, 99(6), 243-248.

Alazzi, K., \& Khawaldeh, A. A. (2008). Do They Really Teach Critical Thinking in the Social Studies Classroom? A Study of Jordanian Secondary School Social Studies Teachers. Teaching \& Learning, 22(2), 93-103.

Al-degether, R. (2009). Teacher educators' opinion and knowledge about critical thinking and the methods they use to encourage critical thinking skills in five female teacher colleges in saudi arabia (Order No. 3352791). Available from ProQuest Dissertations \& Theses Global. (304919096). Retrieved from http://search.proquest.com/docview/304919096?accountid=44936

Al-Hamdi, I. (2004) The Reality of Second Secondary Grade History Teachers' practice of Critical Thinking and Creative Thinking Skills as Seen by Teachers and Principals in the Kingdom of Saudi Arabia. Unpublished Master's Thesis, Al Yarmouk University, Jordan.

Allamnakhrah, A. (2013). Learning critical thinking in Saudi Arabia: Student perceptions of secondary pre-service teacher education programs. Journal of Education and Learning, 2(1), 197-210.

Alwadai, M. (2014). Islamic teachers' perceptions of improving critical thinking skills in Saudi Arabian elementary schools (Order No. 3640673). Available from ProQuest Dissertations \& Theses Global. (1625970780). Retrieved from http://search.proquest.com/docview/1625970780?accountid=44936.

Alwehaibi, H. (2012). Novel program to promote critical thinking among higher education students: Empirical study from Saudi Arabia. Asian Social Science, 8(11), 193-204. doi: 10.5539/ass.v8n11p193.

Ashraah, M. M., AL-Nabrawi, I. M., Shdeifat, S., \& Falah al Ali, T. M. (2012). Critical thinking skills for Islamic education teachers: A study of teachers' perceptions. International Journal Of Academic Research, 4(6), 70-74. doi:10.7813/2075-4124.2012/4-6/B.11.

Choy, S. C., \& Cheah, P. K. (2009). Teacher perceptions of critical thinking among students and its influence on higher education. International Journal of teaching and learning in Higher Education, 20(2), 198-206.

Dewey, J. (1938). Experience and education. New York: Collier Books.

Elder, L., Paul R., \& Cosgrove, R. (2007). Critical Thinking Basic Concepts and Understandings Test. Foundation for Critical Thinking. Retrieved on December 03, 2014 from: http://www.criticalthinking.org/pages/online-criticalthinking-basic-concepts-test/679

Facione, P,A. (1990). Critical thinking: A statement of expert consensus for the purposes of educational assessment and instruction, Millbrae, CA: California Academic Press,

Howie, D. R. (2011). Teaching Students Thinking Skills and Strategies : A Framework for Cognitive Education in Inclusive Settings. London: Jessica Kingsley Publishers.

Lauer, T. (2005). Teaching critical-thinking skills using course content material. Journal of College Science Teaching, 34(6), 34-44.

Klein, G. (2011). Critical thoughts about critical thinking. Theoretical Issues In Ergonomics Science, 12(3), $210-224$. doi:10.1080/1464536X.2011.564485

Kowalczyk, N. Hackworth, R \& Case-smith, J. (2012). Perception of the use of critical thinking methods. Radiologic Technology, 83 (3), 226-237.

McGuinness, C. (2005). Teaching thinking: theory and practice. British journal of educational psychology, Monograph series II (3), 107-126.

Ozkan-Akan, S. (2003). Teachers' perceptions of constraints in improving students' thinking in high school. Unpublished Master Thesis. Ankara: Middle East Technical University.

Qing, Z., Chungeng, Y., Shuyu, Z., Liya, L., \& Lijuan, X. (2012). A preliminary investigation into critical thinking of in-service and pre-service middle school chemistry teachers in Shaanxi province of China. Asia-Pacific Forum On Science Learning \& Teaching, 13(2), 1-13.

Semmar, Y., \& Fakhro, A. (2009). Investigating Critical Thinking Skills Practices in Qatari Elementary Schools. International Journal Of Learning, 16(1), 13-23.

Smith, G. F. (2002). Thinking skills: the question of generality. Journal of curriculum studies, 34,659-678.

Sng, B. B. (2011). Cultural Perceptions of Critical Thinking Skills of Asian Theological College Students. Journal Of Adult Theological Education, 8(2), 153-165. doi:10.1558/JATE.v8i2.153

Stedman, N. R., \& Adams, B. L. (2012). Identifying Faculty's Knowledge of Critical Thinking Concepts and Perceptions of Critical Thinking Instruction in Higher Educaiion. NACTA Journal, 56(2), 9-14.

Tarman, B. (2012). Prospective Teachers' Beliefs and Perceptions about Teaching as a Profession. Educational Sciences: Theory \& Practice, 12(3), 1964-1973.

Weissberg, R. (2013). Critically Thinking about Critical Thinking. Academic Questions, 26(3), 317-328. doi:10.1007/s12129-013-9375-2. 